Article

\title{
Performance of Graphene/Polydimethylsiloxane Surfaces against $S$. aureus and $P$. aeruginosa Single- and Dual-Species Biofilms
}

\author{
Isabel M. Oliveira ${ }^{1,+}$, Marisa Gomes ${ }^{1,+}{ }^{+}$, Luciana C. Gomes ${ }^{1}$ (D), Manuel F. R. Pereira ${ }^{2} \mathbb{D}_{\text {, }}$ \\ Olívia S. G. P. Soares ${ }^{2, *(D)}$ and Filipe J. Mergulhão ${ }^{1, *(D)}$
}

1 LEPABE-Laboratory for Process Engineering, Environment, Biotechnology and Energy, Faculty of Engineering, University of Porto, Rua Dr. Roberto Frias, 4200-465 Porto, Portugal; imoliveira@fe.up.pt (I.M.O.); marisagomes@fe.up.pt (M.G.); luciana.gomes@fe.up.pt (L.C.G.)

2 LSRE-LCM-Laboratory of Separation and Reaction Engineering-Laboratory of Catalysis and Materials, Faculty of Engineering, University of Porto, Rua Dr. Roberto Frias, 4200-465 Porto, Portugal; fpereira@fe.up.pt

* Correspondence: salome.soares@fe.up.pt (O.S.G.P.S.); filipem@fe.up.pt (F.J.M.); Tel.: +351-225081779 (O.S.G.P.S.); +351-225081556 (F.J.M.)

+ These authors contributed equally to this work.

check for updates

Citation: Oliveira, I.M.; Gomes, M.; Gomes, L.C.; Pereira, M.F.R.; Soares, O.S.G.P.; Mergulhão, F.J. Performance of Graphene/Polydimethylsiloxane Surfaces against $S$. aureus and $P$. aeruginosa Single- and Dual-Species Biofilms. Nanomaterials 2022, 12, 355. https://doi.org/10.3390/nano 12030355

Academic Editor: Andrew Ruys

Received: 30 December 2021

Accepted: 19 January 2022

Published: 22 January 2022

Publisher's Note: MDPI stays neutral with regard to jurisdictional claims in published maps and institutional affiliations.

Copyright: (C) 2022 by the authors. Licensee MDPI, Basel, Switzerland. This article is an open access article distributed under the terms and conditions of the Creative Commons Attribution (CC BY) license (https:// creativecommons.org/licenses/by/ $4.0 /)$.

\begin{abstract}
The increasing incidence of implant-associated infections has prompted the development of effective strategies to prevent biofilm formation on these devices. In this work, pristine graphene nanoplatelet/polydimethylsiloxane (GNP/PDMS) surfaces containing different GNP loadings (1, 2, 3,4 , and $5 \mathrm{wt} \%$ ) were produced and evaluated on their ability to mitigate biofilm development. After GNP loading optimization, the most promising surface was tested against single- and dual-species biofilms of Staphylococcus aureus and Pseudomonas aeruginosa. The antibiofilm activity of GNP/PDMS surfaces was determined by the quantification of total, viable, culturable, and viable but nonculturable (VBNC) cells, as well as by confocal laser scanning microscopy (CLSM). Results showed that $5 \mathrm{wt} \%$ GNP loading reduced the number of total (57\%), viable (69\%), culturable (55\%), and VBNC cells (85\%) of S. aureus biofilms compared to PDMS. A decrease of $25 \%$ in total cells and about $52 \%$ in viable, culturable, and VBNC cells was observed for P. aeruginosa biofilms. Dual-species biofilms demonstrated higher resistance to the antimicrobial activity of GNP surfaces, with lower biofilm cell reductions (of up to $29 \%$ when compared to single-species biofilms). Still, the effectiveness of these surfaces in suppressing single- and dual-species biofilm formation was confirmed by CLSM analysis, where a decrease in biofilm biovolume ( $83 \%$ for S. aureus biofilms and $42 \%$ for P. aeruginosa and dualspecies biofilms) and thickness (on average $72 \%$ ) was obtained. Overall, these results showed that pristine GNPs dispersed into the PDMS matrix were able to inhibit biofilm growth, being a starting point for the fabrication of novel surface coatings based on functionalized GNP/PDMS composites.
\end{abstract}

Keywords: graphene; polydimethylsiloxane; Staphylococcus aureus; Pseudomonas aeruginosa; antibiofilm activity; implantable medical devices

\section{Introduction}

Implantable medical devices (IMDs) play an active role in the therapy of different medical conditions, enhancing the quality of life [1,2]. Although they are extremely successful in supporting or even replacing damaged body organs, IMDs (e.g., cardiac implantable devices, hemodialyzers, urinary or central venous catheters, contact lenses, artificial breasts, and orthodontal and orthopedic prosthetics) carry the risk of inducing future infections, seriously affecting the patients' health and even endangering their lives [3-5]. Implantassociated infections (IAIs) present a high incidence, corresponding to $60-70 \%$ of the nosocomial infections reported each year in the United States [6], and are responsible for a severe burden on healthcare systems and high economic costs $[7,8]$. 
IMDs are prone to bacterial adhesion and, consequently, biofilm formation, contributing to the persistence and spread of infection [9]. The implants act as foreign materials in the human body, enabling the colonization of several microbial species that are not eliminated by the host's innate immune system. The predominant microorganisms identified as colonizers of IMDs include Staphylococcus epidermidis and Staphylococcus aureus, which account for 50-60\% of IAIs [10]. However, depending on the type and location of the implant, other species can be found, namely Escherichia coli, Pseudomonas aeruginosa, Enterococcus spp., Candida spp., and Klebsiella pneumoniae [11,12]. Once adhered to the implant surface, the microorganisms form either single- or multi-species biofilms, which are typically less susceptible to antimicrobial treatment $[13,14]$.

To overcome the limitations noted above, it is crucial to develop new strategies that specifically reduce the adhesion and growth of microorganisms [15]. Currently, one of the most promising antimicrobial strategies is the development of antifouling polymeric nanomaterials. These systems include the release of antimicrobial agents (e.g., metals and biocides), contact-killing materials (e.g., antimicrobial peptides), matrix disruptive agents (e.g., enzymes and cationic chelators), or a combination of these approaches $[5,16,17]$. Although there are promising strategies to mitigate IAIs, their application as a coating in IMDs is still limited by the low biocompatibility, the resistance phenomena, the toxicity that originates from the coatings, and the loss of antimicrobial properties over time $[5,18]$.

Due to its remarkable chemical and physical properties, graphene has emerged as a novel material with relevant applications in the biomedical field [19]. This nanomaterial, in its pure form, is characterized by a single-layer sheet of $\mathrm{sp}^{2}$-hybridized carbon atoms with a honeycomb structure [20], and provides multiple advantages: it is easily renewable, easy to prepare and functionalize, and possesses a large surface area, high stability in the physiological environment, and unique mechanical strength [21]. Due to their outstanding antimicrobial activity, graphene-based materials (e.g., graphene nanoplatelets, graphene nanosheets, graphene oxide, and reduced graphene oxide) have been extensively studied for application as coatings/surfaces for biomedical devices [22,23]. However, it is worth noting the use of functionalized graphene-based materials for other applications, including biosensing and bioimaging, gene therapy, tissue engineering, and drug delivery [23,24]. For instance, the use of graphene-based composites as a support to release antimicrobial agents for wound dressing applications has been described $[25,26]$. The good biocompatibility of graphene, which has been improved through functionalization, clearly contributes to its high demand in the biomedical field [22,27].

The antibacterial activity of graphene-based materials involves physical and chemical mechanisms. The most usual antibacterial activity occurs upon direct contact to the bacterial membrane by the sharp edges of graphene sheets, or wrapping and trapping bacterial membranes by the nanosheets [28]. The chemical damage is associated with the oxidative stress originated by the production of molecules known as reactive oxygen species (ROS) [29].

The antimicrobial and anti-adhesive activity of graphene and its derivatives against implant-associated pathogens have been widely addressed, with significant inhibition of biofilm formation or even reduction of mature biofilms [23,30-32]. Despite the interesting results using graphene-based surfaces to prevent bacterial biofilm formation, the use of non-functionalized graphene as a coating for IMDs is still poorly explored and documented $[22,23,29]$. In addition, most of the studies reporting the use of pristine graphene tend to combine it with other materials with expected synergetic effects, such as silver nanoparticles [33,34], cadmium sulfide [35], titanium [36], magnetite [37], or chitosan [32], hindering the in-depth understanding of the effective antibiofilm performance of graphene alone. At the same time, there are a scarce number of studies reporting the employment of graphene to enhance the antibacterial properties of polydimethylsiloxane (PDMS) [38-41], a polymer belonging to the group of silicone elastomers with high applicability in IMDs [42,43]. 
Taking this evidence into account, the primary objective of this study was to optimize the graphene nanoplatelets (GNPs) loading of PDMS surfaces and evaluate the performance of these composites in the mitigation of single- and dual-species biofilms of $S$. aureus and $P$. aeruginosa - two common colonizers of IMDs. As far as we know, this is the first work reporting the antimicrobial activity of pristine GNPs against multi-species biofilms. Furthermore, there are no previous studies addressing the activity of pristine GNPs while incorporated into a polymeric surface against biofilms of the two specific bacterial species under study $-S$. aureus and P. aeruginosa.

\section{Materials and Methods}

Figure 1 presents the flowchart of the experimental work fully described in the upcoming sections.

\section{Production and characterization of GNP/PDMS composites}

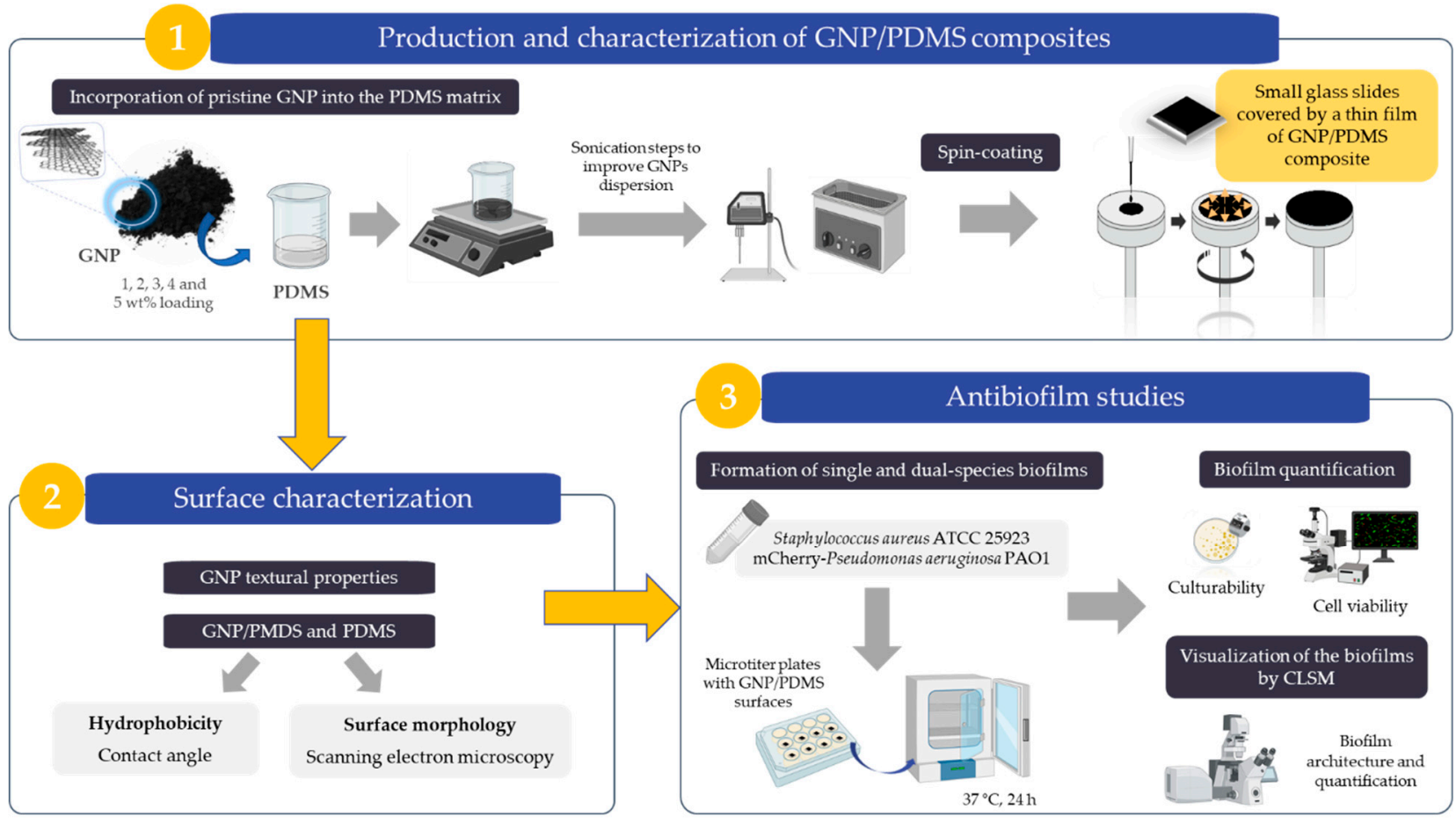

Figure 1. Representative scheme of the experimental tasks performed within the scope of this work.

\subsection{Production of GNP/PDMS Composites}

To prepare GNP/PDMS surfaces, commercially available GNPs aggregates (Alfa Aesar, Thermo Fisher Scientific, Erlenbachweg, Germany), PDMS elastomer (Sylgard 184 Part A, Dow Corning, Midland, MI, USA), and curing agent (Sylgard 184 Part B, Dow Corning) were used.

The GNP/PDMS composites were produced through a bulk mixing process by incorporation of GNPs into the PDMS base elastomer (Part A) as detailed by Vagos et al. [44]. The GNPs were first incorporated at different loadings $(1,2,3,4$, and $5 \mathrm{wt} \%)$ to determine the most efficient GNP load to decrease bacterial biofilm formation. To improve the GNP dispersion, the mixture was stirred for $30 \mathrm{~min}$ at $500 \mathrm{rpm}$ and then sonicated (Hielscher UP400S, at $200 \mathrm{~W}$ and $12 \mathrm{kHz}$ ) for $60 \mathrm{~min}$. After that, the composites were kept in an ultrasound bath (Selecta Ultrasons, Lisbon, Tecnilab, Portugal) for $30 \mathrm{~min}$ to remove the remaining air bubbles. At that point, the curing agent (Part B) was added to the elastomer/GNP mixture (in an A:B ratio of 10:1) and gently shaken. The GNP composites were placed as a thin layer on top of glass slides $(1 \times 1 \mathrm{~cm}$, Vidraria Lousada, Lda, Lousada, Portugal) through spin coating (Spin150 PolosTM, Caribbean, The Netherlands) for $1 \mathrm{~min}$ with a $500 \mathrm{rpm}$ ramp to $6000 \mathrm{rpm}$. Likewise, PDMS surfaces were produced as control [45]. 


\subsection{Surface Characterization}

\subsubsection{GNP Textural Properties}

Nitrogen adsorption-desorption isotherms were obtained using a Quantachrome NOVA 4200e multi-station equipment (Quantachrome Instruments, Boynton Beach, FL, USA) at $-196^{\circ} \mathrm{C}$. These isotherms were used to assess the textural properties of the GNP sample after degasification at $120^{\circ} \mathrm{C}$ for $3 \mathrm{~h}$ under vacuum. The surface area of the GNP sample was obtained according to the Brunauer-Emmett-Teller method $\left(S_{\mathrm{BET}}\right)$, and the total pore volume $\left(V_{\mathrm{p}}\right)$ was obtained from the amount of $\mathrm{N}_{2}$ adsorption at a relative pressure $p / p_{0}$ of 0.99 [46]. The external surface area $\left(\mathrm{S}_{\text {meso }}\right)$ and micropore volume $\left(\mathrm{V}_{\text {micro }}\right)$ were also acquired applying the t-method.

\subsubsection{GNP/PMDS and PDMS Hydrophobicity}

The contact angles of PDMS and GNP/PDMS surfaces at 1, 2, 3, 4, and $5 \mathrm{wt} \%$ GNP were obtained through the sessile drop method (OCA 15 Plus, Dataphysics, Germany). Contact angles with three pure liquids-water, formaldehyde, and $\alpha$-bromonaphthalene-were estimated to determine the surface tension elements of the target surfaces. The surface tension components of the noted liquids $(I)$ were collected from the literature [47]. Surface hydrophobicity was then assessed by the method of van Oss et al. [48-50]. In this method, the hydrophobicity level of a surface $(i)$ is defined as the free energy of interaction between two elements of that surface immersed in water $(w)-\Delta G_{i w i}$. If the interaction between the two elements is greater than the interaction of each element with water $\left(\Delta G_{i w i}<0 \mathrm{~mJ} \mathrm{~m}^{-2}\right)$, the surface is hydrophobic. Contrarily, if $\Delta G_{i w w i}>0 \mathrm{~mJ} \mathrm{~m}^{-2}$, the material is considered hydrophilic. The value of $\Delta G_{i w i}$ was obtained from the surface tension components of the interacting elements in conformity with Equation (1):

$$
\Delta G_{i w i}=-2\left(\sqrt{\gamma_{i}^{L W}}-\sqrt{\gamma_{w}^{L W}}\right)^{2}+4\left(\sqrt{\gamma_{i}^{+} \gamma_{w}^{-}}+\sqrt{\gamma_{i}^{-} \gamma_{w}^{+}}-\sqrt{\gamma_{i}^{+} \gamma_{i}^{-}}-\sqrt{\gamma_{w}^{+} \gamma_{w}^{-}}\right),
$$

where $\gamma^{L W}$ corresponds to Lifshitz-van der Waals element of the surface free energy, and $\gamma^{+}$and $\gamma^{-}$are the electron acceptor and electron donor parameters, respectively, of the Lewis acid-base component $\left(\gamma^{A B}\right)$, with $\gamma^{A B}=2 \sqrt{\gamma^{+} \gamma^{-}}$.

The surface tension components were determined by the simultaneous solving of three equations similar to Equation (2):

$$
(1+\cos \theta) \gamma_{i}^{T O T}=2\left(\sqrt{\gamma_{i}^{L W} \gamma_{I}^{L W}}+\sqrt{\gamma_{i}^{+} \gamma_{I}^{-}}+\sqrt{\gamma_{i}^{-} \gamma_{I}^{+}}\right),
$$

where $\theta$ is the contact angle and $\gamma^{T O T}=\gamma^{L W}+\gamma^{A B}$.

\subsubsection{GNP/PMDS and PDMS Morphology}

The surface morphology and the distribution of GNPs into the PDMS matrix were evaluated by scanning electron microscopy (FEI Quanta 400 FEG ESEM/EDAX Genesis X4M microscope; FEI Europe, Eindhoven, The Netherlands).

\subsection{Antibiofilm Studies}

\subsubsection{Bacterial Strain and Culture Conditions}

The antimicrobial/anti-adhesive activity of GNP/PDMS coatings was assessed using a Staphylococcus aureus reference strain (ATCC 25923) and a mCherry-Pseudomonas aeruginosa PAO1 strain because these two bacteria are frequently found in implantable medical devices [51]. The mCherry-expressing strain enabled P. aeruginosa detection in dual-species biofilms. Bacteria were stored at $-80{ }^{\circ} \mathrm{C}$ in Luria-Bertani Broth (LB) medium (Thermo Fisher Scientific, Waltham, MA, USA). Before each experiment, both bacteria were spread on Plate Count Agar (PCA; Merck KGaA, Darmstadt, Germany) petri dishes and incubated overnight at $37^{\circ} \mathrm{C}$. 
LB broth was then inoculated with individual colonies harvested from PCA plates and incubated overnight at $37^{\circ} \mathrm{C}, 160 \mathrm{rpm}$. In the specific case of $P$. aeruginosa cultures, tetracycline antibiotic $\left(1.25 \mathrm{mg} \mathrm{L}^{-1}\right)$ was applied to select the transformed bacteria [52]. After centrifugation at $3772 \times g, 18^{\circ} \mathrm{C}$ for $10 \mathrm{~min}$ (Eppendorf Centrifuge 5810R, Eppendorf, Hamburg, Germany), the pellet was resuspended in fresh LB medium, and a final cell suspension with an optical density at $610 \mathrm{~nm}$ of 0.1 (corresponding to $1 \times 10^{8}$ colonyforming units per $\mathrm{mL}, \mathrm{CFU} \mathrm{mL}^{-1}$ ) was prepared. To form dual-species biofilms, the bacterial suspensions of $S$. aureus and P. aeruginosa were mixed in a ratio of $1: 1$, maintaining the final cell concentration of $1 \times 10^{8} \mathrm{CFU} \mathrm{mL}^{-1}$.

\subsubsection{Antibiofilm Assays}

To assess biofilm formation on GNP/PDMS composites, the composites were first sterilized through UV radiation for $1 \mathrm{~h}$. Sterilized surfaces of PDMS, and 1, 2, 3, 4, and $5 \mathrm{wt} \%$ GNP/PDMS were placed on the microplate wells (12-well plate, VWR International, Carnaxide, Portugal) and inoculated with $3 \mathrm{~mL}$ of the bacterial suspension. Plates were incubated at $37^{\circ} \mathrm{C}$ for $24 \mathrm{~h}$ under static conditions.

\section{Biofilm Quantification}

After $24 \mathrm{~h}$ of biofilm formation, GNP/PDMS surfaces were detached from the microplate wells, immersed in $2 \mathrm{~mL}$ of saline solution, and vigorously agitated for $3 \mathrm{~min}$ to obtain biofilm cell suspensions. The number of culturable cells was evaluated by spreading the biofilm suspensions on PCA (after proper dilution in saline solution) followed by CFU counts. The biofilm total and viable cells were assessed by staining biofilm suspensions with the Live/Dead kit (Invitrogen Life Technologies, Alfagene, Portugal) [53] and subsequent analysis in an epifluorescence microscope (Leica DM LB2, Wetzlar, Germany). The number of viable but nonculturable (VBNC) cells was also calculated as the difference between the number of viable and culturable cells [54].

\section{Visualization of the Biofilms Using Confocal Laser Scanning Microscopy (CLSM)}

The spatial structure of single- and dual-species biofilms of P. aeruginosa and S. aureus on PDMS and GNP/PDMS surfaces was assessed by CSLM as described by Lima et al. [7]. S. aureus and P. aeruginosa + S. aureus biofilms were first counterstained with $6 \mu \mathrm{M} \mathrm{SYTO}^{\circledR} 9$ (Invitrogen Life Technologies, Alfagene, Portugal). All biofilm samples were then observed using a $40 \times$ water immersion objective lens (Leica Microsystems, Wetzlar, Germany) in an inverted microscope Leica DMI6000-CS with $488 \mathrm{~nm}$ argon and $633 \mathrm{~nm}$ helium-neon lasers. Image stacking was acquired with a $1 \mu \mathrm{m}$ thickness for each sample at a minimum of five random fields. Image processing was performed using the IMARIS 9.1 software package (Bitplane, Zurich, Switzerland) for modelling in two and three dimensions [55]. The CLSM acquisitions were analyzed by the plug-in COMSTAT2 associated with the ImageJ software to determine biofilm structural parameters such as biovolume $\left(\mu \mathrm{m}^{3} \mu \mathrm{m}^{-2}\right)$ and average thickness $(\mu \mathrm{m})[56]$.

\subsection{Statistical Analysis}

Statistical analysis was conducted in GraphPad Prism 8 version. After assessing data normality with the Shapiro-Wilk test, the most appropriate tests for mean comparison were applied. The Kruskal-Wallis test was used to evaluate the differences between the contact angles of PDMS, and 1, 2, 3, 4, and $5 \mathrm{wt} \%$ GNP/PDMS surfaces, as this variable was not normally distributed. Differences in the number of culturable cells obtained for PDMS, and 1, 2, 3, 4, and $5 \mathrm{wt} \%$ GNP/PDMS surfaces were evaluated using one-way analysis of variance (ANOVA). The Mann-Whitney test was applied to evaluate the differences in the number of total, viable, culturable, and VBNC cells between PDMS and $5 \mathrm{wt} \%$ GNP/PDMS surfaces, as the variables were normally distributed. Quantitative parameters obtained from confocal microscopy, namely biovolume and thickness, were compared using ANOVA. Statistical significance was indicated as * for $p<0.05,{ }^{* *}$ for $p<0.01,{ }^{* *}$ for $p<0.001$, and 
**** for $p<0.0001$. All experiments were performed in triplicate, and the results presented as mean \pm standard deviation (SD) or error (SE).

\section{Results and Discussion}

\subsection{Graphene Characterization}

As particle morphology affects the microstructure and porosity of nanocomposites, the characterization of the graphene sample is of extreme importance [57]. Therefore, the textural properties of GNP powders were first assessed by the $\mathrm{N}_{2}$ adsorption-desorption isotherms.

The isotherms of the GNP sample fit the Type-II isotherm profile, characteristic of carbon materials with slit-shaped mesoporosity, according to IUPAC classification [58]. The physisorption isotherms obtained are in accordance with those described in previous reports on pristine GNPs [59,60]. The presence of an H3 type hysteresis loop indicates capillary condensation phenomena and mesoporous materials that comprise aggregates of plate-like particles [61]. The sharp rise of $\mathrm{N}_{2}$ uptake at low relative pressure is quite characteristic of microporous materials [62].

The results of $\mathrm{N}_{2}$ adsorption-desorption isotherms are reflected in the specific surface area $\left(\mathrm{S}_{\mathrm{BET}}\right)$, external surface area $\left(\mathrm{S}_{\text {meso }}\right)$, micropore volume $\left(\mathrm{V}_{\text {micro }}\right)$, and total pore volume $\left(V_{p}\right)$ of GNPs, textural parameters that are summarized in Table 1.

Table 1. Textural properties of graphene nanoplatelets (GNPs).

\begin{tabular}{ccccc}
\hline Sample & $\begin{array}{c}S_{\text {BET }} \\
\left(\mathrm{m}^{2} \mathrm{~g}^{-\mathbf{1}}\right)\end{array}$ & $\begin{array}{c}S_{\text {meso }} \\
\left(\mathrm{m}^{\mathbf{2}} \mathrm{g}^{-\mathbf{1}}\right)\end{array}$ & $\begin{array}{c}V_{\text {micro }} \\
\left(\mathrm{cm}^{3} \mathrm{~g}^{-\mathbf{1}}\right)\end{array}$ & $\begin{array}{c}V \mathrm{p} p / p_{0}=\mathbf{0 . 9 9} \\
\left(\mathrm{cm}^{\mathbf{3}} \mathrm{g}^{-\mathbf{1}}\right)\end{array}$ \\
\hline GNPs & 464 & 363 & 0.045 & 0.535 \\
\hline
\end{tabular}

As one might expect, the results of $\mathrm{N}_{2}$ adsorption-desorption isotherms proved that GNPs present, along with the microporous character $\left(V_{\text {micro }}\right.$ of about $\left.0.05 \mathrm{~cm}^{3} \mathrm{~g}^{-1}\right)$, an extended mesoporosity, and a high specific surface area, which is in good agreement with that provided by the manufacturer. The obtained surface area is still significantly lower than the theoretical surface area of individual graphene sheets $\left(2630 \mathrm{~m}^{2} \mathrm{~g}^{-1}\right)$ [63]. However, these results are consistent with the GNP structure, which is characterized by overlapped graphene layers that limit nitrogen adsorption, as previously noted by Srinivas et al. [64]. As it is well known that high surface area potentiates the interaction with bacterial cells and, consequently, cell death [65], the use of these GNPs for antimicrobial applications is a promising approach. Furthermore, several studies reported the potential of microporous materials in the biomedical field for antibacterial applications [66].

\subsection{Physicochemical Characterization of GNP/PDMS Surfaces}

Because the surface properties, such as hydrophobicity and charge, are known to affect the extent of cell adhesion and biofilm formation [67], the GNP/PDMS surfaces were first characterized by contact angle measurements and the calculation of the respective free energy of interaction $\left(\Delta \mathrm{G}_{i w i}\right)$ among the two entities of a specific surface (i) when immersed in water $(w)$ (Table 2).

The results showed that tested surfaces presented a hydrophobic behaviour. This evidence is in accordance with previously published studies using graphene-based materials [68-70], including pristine GNPs embedded in a PDMS matrix [38]. Although it is not possible to observe a linear trend in the evolution of hydrophobicity with the incorporation of increasing GNP loadings, the enhancement of surface hydrophobicity with the incorporation of $5 \mathrm{wt} \%$ is quite remarkable. Indeed, it was possible to verify that $5 \mathrm{wt} \%$ GNP/PDMS surfaces showed a higher value for the water contact angle $(p<0.0001)$ compared to PDMS. 
Table 2. Contact angles with water $\left(\theta_{w}\right)$, formamide $\left(\theta_{F}\right)$, and $\alpha$-bromonaphthalene $\left(\theta_{B}\right)$ for bare polydimethylsiloxane (PDMS) and GNP/PDMS surfaces. The respective free energy of interaction $\left(\Delta G_{i w i}\right)$ is also included.

\begin{tabular}{|c|c|c|c|c|}
\hline \multirow{2}{*}{ Surface } & \multicolumn{3}{|c|}{ Contact Angle $\left(^{\circ}\right)$} & \multirow{2}{*}{$\begin{array}{c}\begin{array}{c}\text { Hydrophobicity } \\
\left(\mathrm{mJ} \mathrm{m}^{-2}\right)\end{array} \\
\Delta G_{i w i}\end{array}$} \\
\hline & $\theta_{w}$ & $\theta_{F}$ & $\theta_{B}$ & \\
\hline PDMS & $110.2 \pm 3.6$ & $112.4 \pm 3.1$ & $90.5 \pm 4.9$ & -50.2 \\
\hline $1 \mathrm{wt} \%$ GNP/PDMS & $108.6 \pm 2.2$ & $104.1 \pm 3.3$ & $82.5 \pm 3.5$ & -58.9 \\
\hline $2 \mathrm{wt} \%$ GNP/PDMS & $110.4 \pm 1.9$ & $105.7 \pm 4.5$ & $88.2 \pm 3.6$ & -63.1 \\
\hline $3 w t \%$ GNP/PDMS & $110.3 \pm 1.6$ & $105.5 \pm 2.7$ & $88.6 \pm 3.1$ & -57.2 \\
\hline $4 \mathrm{wt} \%$ GNP/PDMS & $111.9 \pm 2.3$ & $107.9 \pm 5.7$ & $92.8 \pm 2.8$ & -65.5 \\
\hline $5 \mathrm{wt} \%$ GNP/PDMS & $121.8 \pm 3.3$ & $113.9 \pm 3.6$ & $102.4 \pm 4.1$ & -87.7 \\
\hline
\end{tabular}

Considering that the topography of nanocomposite films may significantly influence the cell adhesion behaviour [71], the characterization of $5 \mathrm{wt} \%$ GNP/PDMS surfaces was supplemented by SEM analysis (Figure 2).

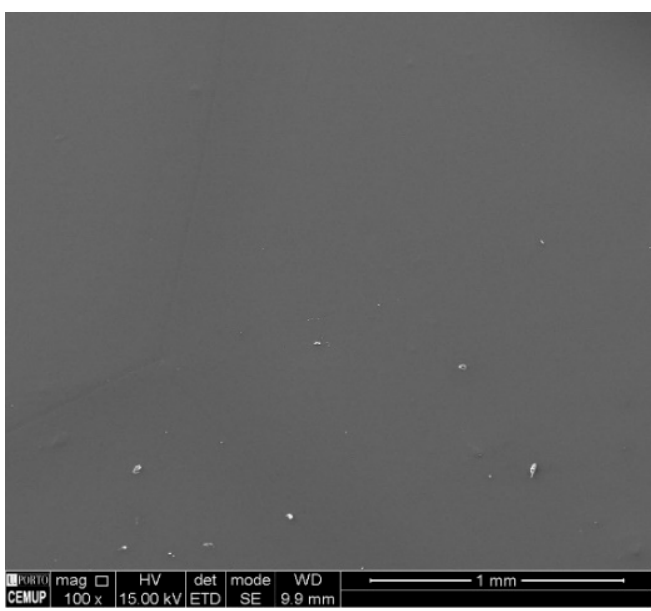

(a)

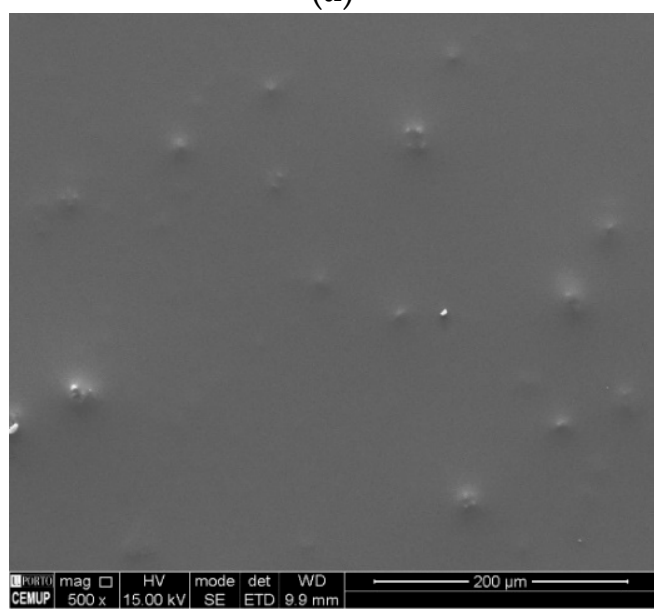

(c)

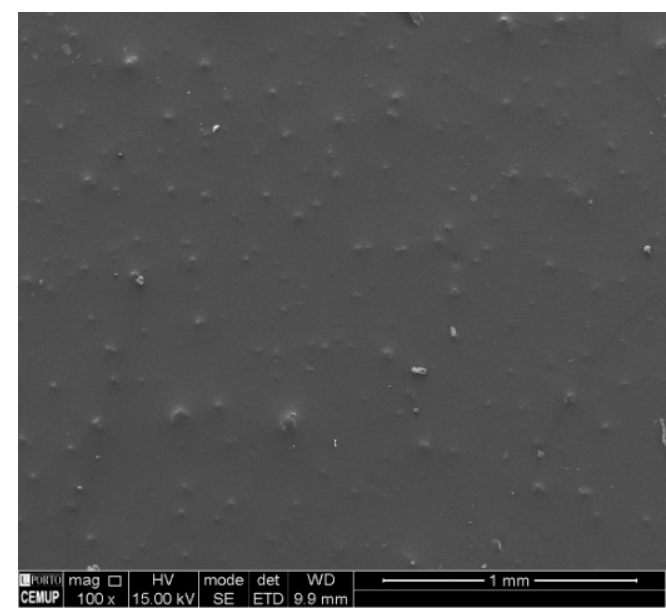

(b)

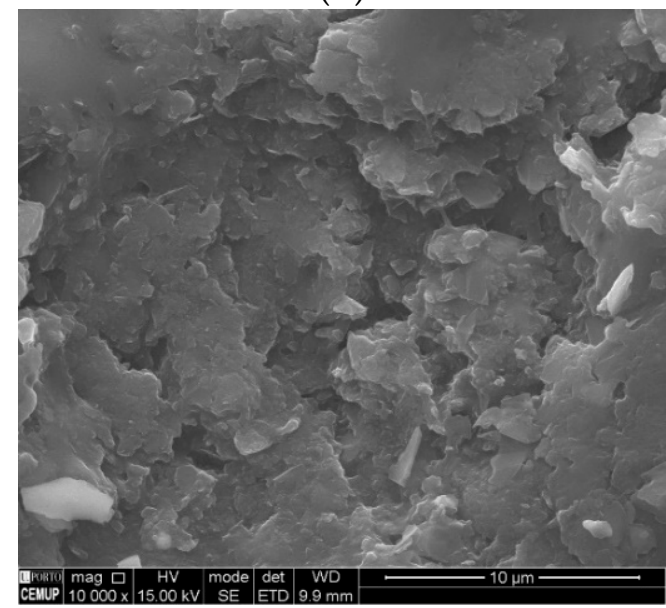

(d)

Figure 2. Scanning electron microscopy (SEM) images of (a) PDMS (magnification of $100 \times$ ) and $5 \mathrm{wt} \%$ GNP/PDMS surfaces with a magnification of (b) $100 \times$, (c) $500 \times$, and (d) $10,000 \times$.

From the SEM images, it was possible to draw some conclusions regarding the overall incorporation and distribution of GNPs into the PDMS matrix. Although some bigger conglomerates still exist, reflecting the layer-stacked compact structure of GNPs (which 
results from the strong $\pi-\pi$ interactions between graphene nanoplatelets) [72], in general, GNPs were uniformly dispersed into the PDMS network (Figure 2b,c). This dispersion uniformity guarantees a larger exposure of the surface of GNPs to bacterial cells and, potentially, higher antimicrobial activity $[28,73]$. The typical flake-like structure of GNPs is perfectly evidenced at higher magnifications (Figure $2 \mathrm{~d}$ ).

\subsection{Biological Characterization}

The antibiofilm activity of PDMS surfaces containing different GNP loadings was first assessed against $S$. aureus ATCC 25923. After $24 \mathrm{~h}$ of incubation with 1, 2, 3, 4, and $5 \mathrm{wt} \%$ GNP/PDMS composites, the culturable cells were quantified (Figure 3). The addition of GNPs to the PDMS matrix resulted in a decrease in cell culturability. A total reduction of up to $55 \%$ was achieved for the $5 \mathrm{wt} \%$ GNP/PDMS surface, which was chosen for further assays, although there were no statistically significant differences between GNP loadings. These results are in line with those found in the literature, where higher concentrations of graphene derivatives have demonstrated a higher bactericidal or bacteriostatic activity [74-76].

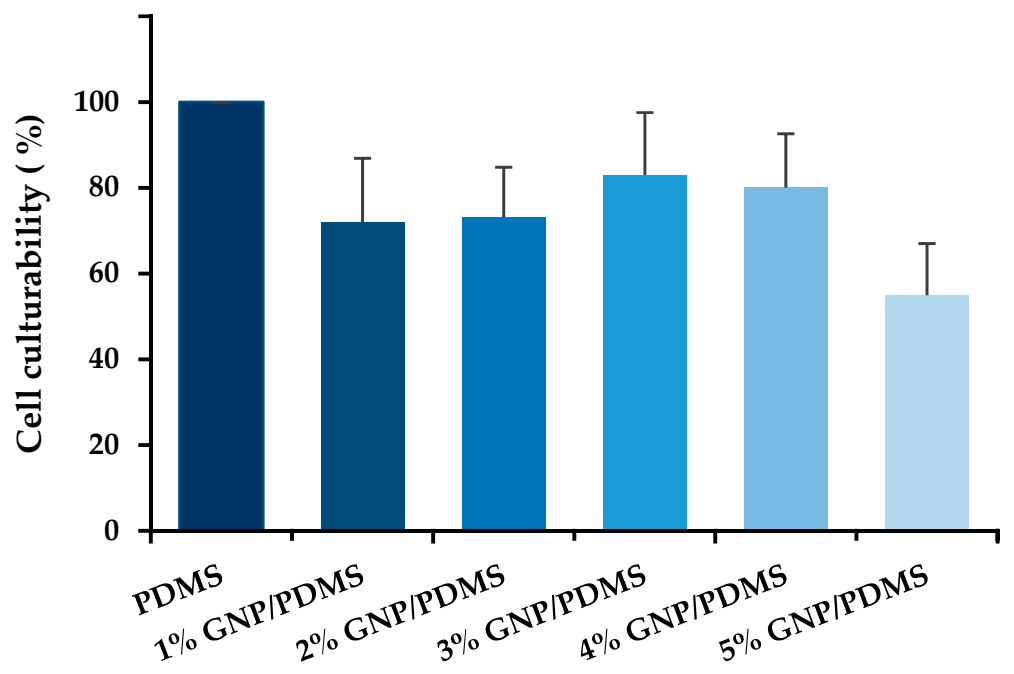

Figure 3. Percentage of $S$. aureus culturable cells after $24 \mathrm{~h}$ of biofilm formation on PDMS (control), and 1, 2, 3, 4, and $5 \mathrm{wt} \%$ GNP/PDMS composites. The means \pm standard error (SE) are presented.

The results of $S$. aureus culturability were supported by the contact angle measurements, which showed higher hydrophobicity levels for $5 \mathrm{wt} \%$ GNP/PDMS composite materials compared to the other tested surfaces. Some studies reported the efficient use of hydrophobic and superhydrophobic surfaces to reduce bacterial adhesion (including of $S$. aureus and P. aeruginosa) and, consequently, biofilm formation [77,78]. The limited antibacterial activity shown by pristine GNP/PDMS composites (reductions of on average $26 \%$; Figure 3), especially those of lower loads, may be explained by the existence of vigorous inter-plane interactions that, by inducing the formation of stronger agglomerates, can reduce the available surface area and, therefore, hinder the GNP mode of action [29].

The $5 \mathrm{wt} \%$ GNP/PDMS surface was evaluated in subsequent assays with singleand dual-species biofilms of $S$. aureus and P. aeruginosa, where its antibiofilm activity was assessed by means of total, viable, culturable, and VBNC cells quantification, and confocal microscopy. By choosing these specific microorganisms, a better understanding of the GNP antibiofilm performance against Gram-positive (S. aureus) and Gram-negative (P. aeruginosa) bacteria can be achieved.

The antibiofilm activity of $5 \mathrm{wt} \%$ GNP/PDMS surfaces against single-species biofilms of $S$. aureus and P. aeruginosa is shown in Figure 4. The analysis of biofilm cells indicated that S. aureus biofilm (Figure 4a) grown on $5 \mathrm{wt} \%$ GNP/PDMS surfaces presented significant 
reductions in the number of total (51\%), viable (69\%), and VBNC cells $(85 \%)$ compared to PDMS $(p<0.0001)$. However, the reduction achieved for the culturable cells $(55 \%$ compared to PDMS) was not statistically significant ( $p>0.05$, Figures 3 and $4 a)$.

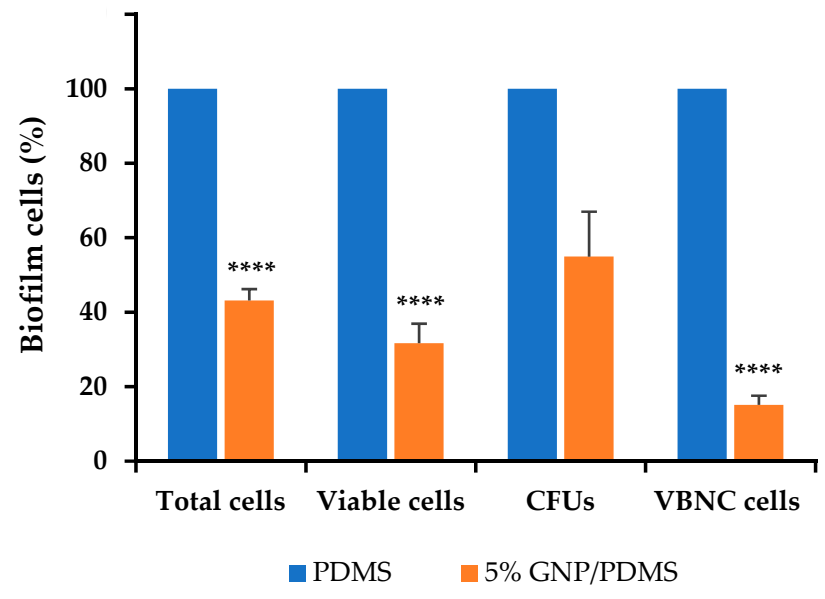

(a)

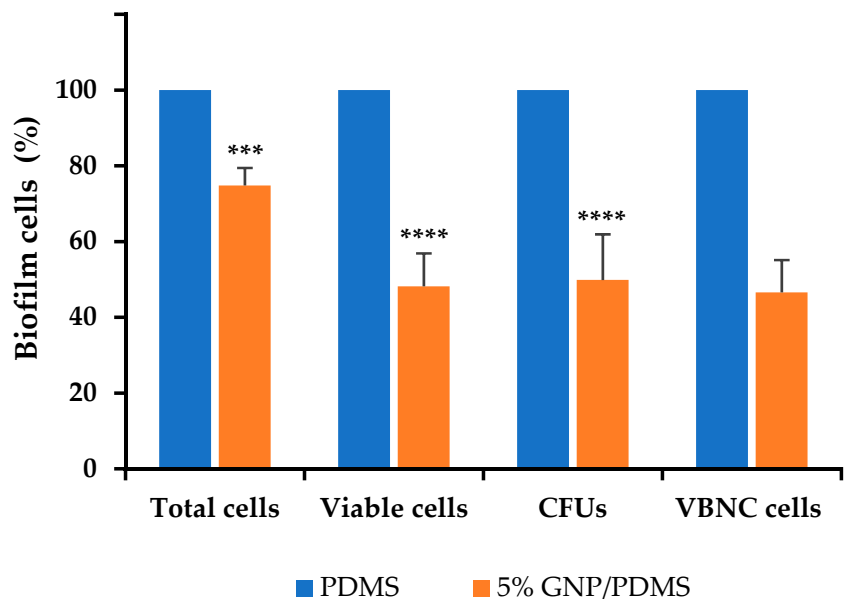

(b)

Figure 4. Percentage of S. aureus (a) and P. aeruginosa (b) single-species biofilm cells on PDMS (control) and $5 \mathrm{wt} \% \mathrm{GNP} / \mathrm{PDMS}$ composites. The means $\pm \mathrm{SE}$ are presented. Significant differences compared with PDMS are represented for $p<0.001$ by ${ }^{* * *}$ and $p<0.0001$ by ${ }^{* * * *}$.

Regarding P. aeruginosa (Figure 4b), biofilms formed on $5 \mathrm{wt} \%$ GNP/PDMS surfaces presented lower reduction percentages of total $(25 \%, p<0.001)$, viable $(52 \%, p<0.0001)$, and VBNC cells $(53 \%, p>0.05)$ compared to PDMS. When compared with $S$. aureus biofilms, the same extent of reduction of cell culturability was observed (51\% compared to PDMS, $p<0.0001)$.

The antimicrobial and antibiofilm activity of graphene-based nanocomposites against S. aureus and P. aeruginosa was previously reported in other studies. However, those were studies performed with functionalized graphene-based materials, including graphene oxide [79-82] or reduced graphene oxide [83,84]. Additionally, although some studies report the antimicrobial use of GNP against common causative microorganisms of IAIs $[38,73,85-87]$, to the best of our knowledge, only two publications refer to the antimicrobial activity of GNPs against $S$. aureus and P. aeruginosa, and none of these makes use of pristine GNPs incorporated into a surface [88,89]. Concerning the greater efficacy of GNPs against $S$. aureus in comparison to P. aeruginosa [81], earlier publications also reported that Gram-positive bacteria are more susceptible to graphene-based materials than Gramnegative bacteria [90,91]. This is mainly due to differences in the cell wall structure [91]. The outer membrane layer in Gram-negative bacteria can act as a protective barrier against graphene exposure compared to Gram-positive bacteria [90].

Overall, these results suggest that loading PDMS with $5 \mathrm{wt} \%$ GNPs presents antiadhesive and antimicrobial properties against both strains, also exerting an effective role in reducing the percentage of VBNC cells, particularly for S. aureus (85\%). Given the involvement of these cells in the recurrence of infections [54], our results indicate that $5 \mathrm{wt} \%$ GNP/PDMS surfaces may be advantageous for application in IMDs. At the same time, as non-oxidized nanoplatelets induce lower ROS production, they can be considered safer materials for use as antimicrobial agents compared with their functionalized derivatives [92].

Considering that in the natural environment biofilms are characterized by multispecies communities, and that the investigations carried out so far failed to predict the antibiofilm performance of GNP composites on this scenario, $5 \mathrm{wt} \%$ GNP/PDMS surfaces were tested against dual-species biofilms of S. aureus and P. aeruginosa (Figure 5). It was possible to observe lower reduction percentages of total $(24 \%)$, viable $(23 \%)$, culturable 
(20\%), and VBNC cells (29\%) compared to PDMS. Therefore, the antibiofilm activity of $5 \mathrm{wt} \%$ GNP/PDMS surfaces was higher in single- than in dual-species biofilms. However, there was still a significant reduction in the number of total and viable cells $(p<0.0001)$, hence these GNPs constitute promising materials in this field.

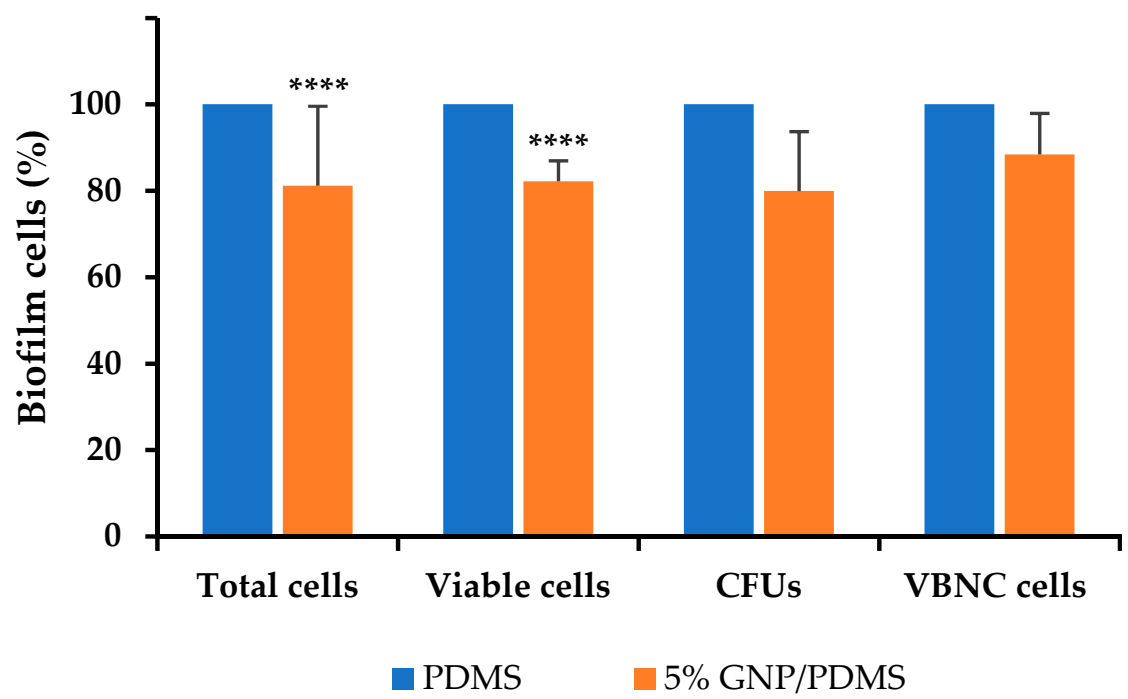

Figure 5. Percentage of S. aureus + P. aeruginosa biofilm cells on PDMS (control) and $5 \mathrm{wt} \%$ GNP/PDMS composites. The means \pm SE are presented. Significant differences compared with PDMS are represented for $p<0.0001$ by ${ }^{* * * *}$.

The cell culturability of dual-species biofilms also showed that the dominant strain in co-culture biofilms was undoubtedly the Gram-negative P. aeruginosa, with a percentage of $93 \%$ and $88 \%$ on PDMS and $5 \mathrm{wt} \%$ GNP/PDMS composites, respectively (Figure S2a in Supplementary Material). These outcomes are in agreement with previously reported studies, which demonstrated that $P$. aeruginosa inhibits the growth of $S$. aureus in dualspecies biofilms $[7,93,94]$. The higher percentage of P. aeruginosa in the co-culture may justify the similarity of behaviours between the single-species biofilms of this Gram-negative bacteria and the mixed ones, which showed higher overall resistance to GNP/PDMS composites.

Representative CLSM images of single-species biofilms of P. aeruginosa and S. aureus and dual-species biofilms on PDMS (control surface) and GNP/PDMS composites are shown in Figure 6.

Concerning single-species biofilms, marked variability in the three-dimensional (3D) structure of biofilms could be observed between the bacterial strains after $24 \mathrm{~h}$ of biofilm growth, regardless of the surface material tested (Figure 6a-d). P. aeruginosa completely covered the surface, developing dense and thick biofilms (Figure 6a,b), whereas the $S$. aureus strain formed highly heterogeneous biofilms consisting of cell aggregates dispersed on the surface (Figure $6 c, d$ ). This visual information was supported through the calculated structural parameters of biofilm biovolume and thickness (Figure 7a,b).

Indeed, P. aeruginosa formed biofilms which had on average $74 \%$ more biovolume and were $47 \%$ thicker than staphylococcal biofilms. Looking at the surface effect, the PDMS surfaces showed the highest biofilm amount and thickness (shadow projection on the right of Figure $6 a, c)$ when compared to the graphene-based surface (Figure $6 b, d$ ). In fact, the GNP/PDMS composite was able to reduce the P. aeruginosa and S. aureus biovolume and biofilm thickness compared to the PDMS surface $(p<0.01$, Figure 7a,b). However, whereas the decrease in biofilm thickness was similar for both strains (approximately 71\%), the biovolume reduction on the surface containing graphene was higher for S. aureus than for P. aeruginosa ( $83 \%$ versus $42 \%$ reduction). This result is in agreement with that obtained by epifluorescence microscopy (Figure 4), in which the reduction in the total cell number 
between the PDMS and $5 \mathrm{wt} \%$ GNP/PDMS surface was $57 \%$ for S. aureus biofilms and only 25\% for Pseudomonas biofilm.

\section{P. aeruginosa}

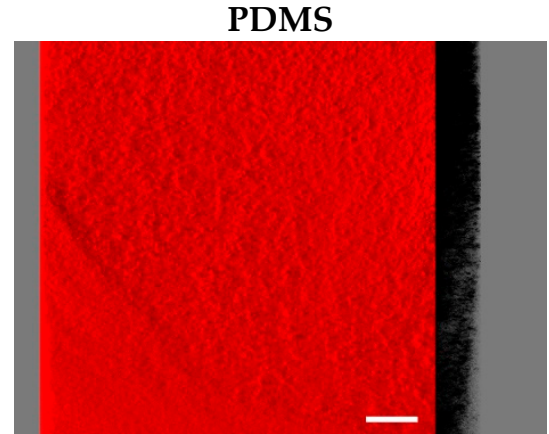

(a)

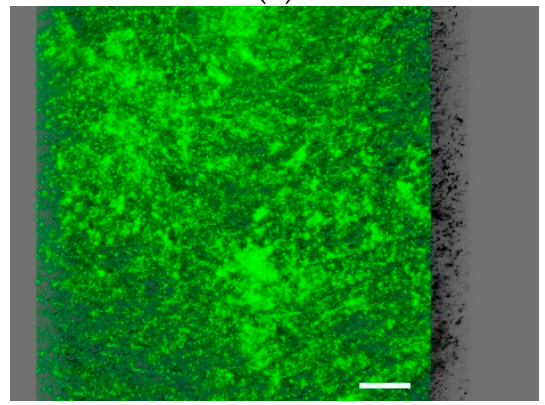

(c)

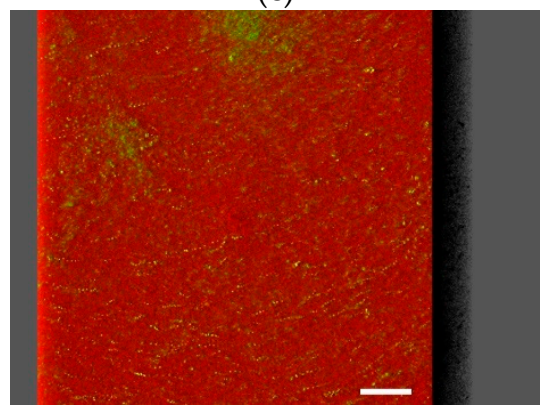

(e)
5 wt $\%$ GNP/PDMS

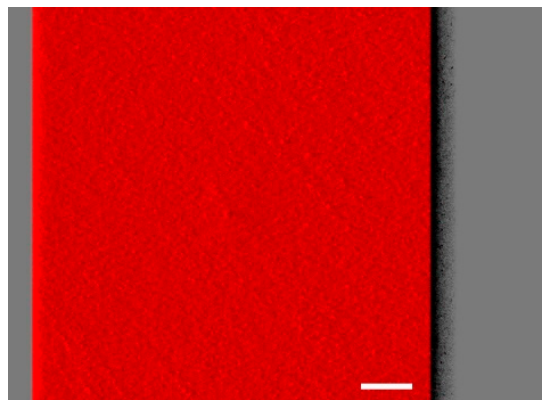

(b)

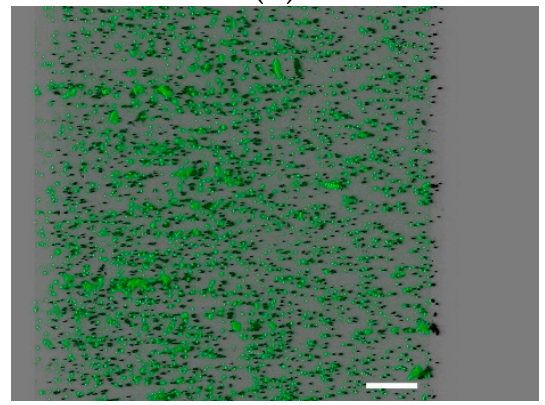

(d)

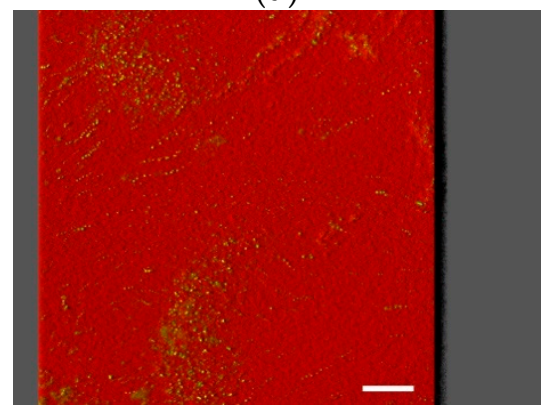

(f)

Figure 6. Single-species biofilms of (a,b) P. aeruginosa and (c,d) S. aureus, and (e,f) mixed biofilms of $P$. aeruginosa (in red) and S. aureus (in green) formed on PDMS (left images) and $5 \mathrm{wt} \%$ GNP/PDMS (right images). These pictures were extracted from confocal files by IMARIS software and present an aerial view of biofilm structures. The shadow projection on the right represents the biofilm thickness. Scale bars are $50 \mu \mathrm{m}$.

Figure 6e,f shows the architecture of dual-species biofilms of P. aeruginosa and S. aureus grown on PDMS and $5 \mathrm{wt} \%$ GNP/PDMS surfaces, respectively. Dual-species biofilms were quite dense and thick as those formed by P. aeruginosa alone (Figure 6a,b). Nevertheless, as for the single-species biofilms (Figure 6a-d), less biofilm amount was observed on the graphene composite compared to PDMS. The quantitative results confirmed the similarity of biovolume and thickness values between dual-species biofilms and P. aeruginosa biofilms (Figure 7), regardless of the tested surface. Additionally, biofilms developed on GNP/PDMS had $42 \%$ less biovolume and $74 \%$ less thickness than on PDMS coating, reinforcing the antiadhesive and antimicrobial activities of this surface in typically more adverse conditions such as the presence of different microbial species.

The CLSM study also revealed that the dominant strain in co-culture biofilms was clearly the Gram-negative bacterium P. aeruginosa (Figure 6e,f, and Figures S1 and S2b in Supplementary Material). A small number of $S$. aureus cells were heterogeneously distributed across surfaces (Figure 6e,f and Figure S1 in Supplementary Material), and the 
percentage of S. aureus population in biofilms was approximately 11\% (Figure S2 in Supplementary Material). This suggests a strong antagonistic behavior by $P$. aeruginosa towards the Gram-positive bacterium S. aureus. In terms of vertical distribution within biofilms, S. aureus was relatively more abundant at the top, whereas the bottom layers of the biofilm consisted predominantly of Pseudomonas cells (Figure S2 in Supplementary Material).

\section{P. aeruginosa}
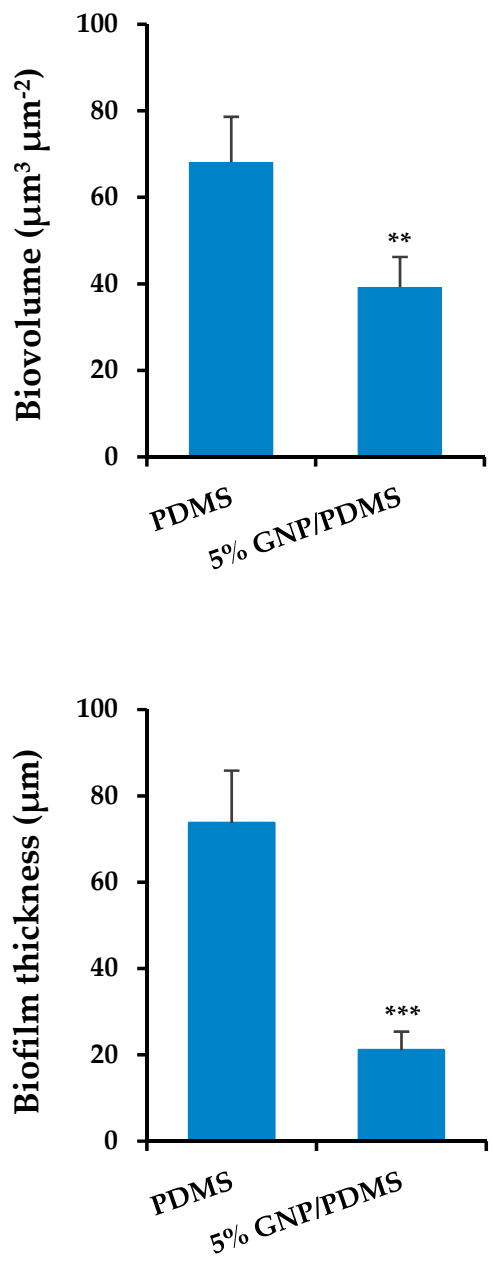

S. aureus

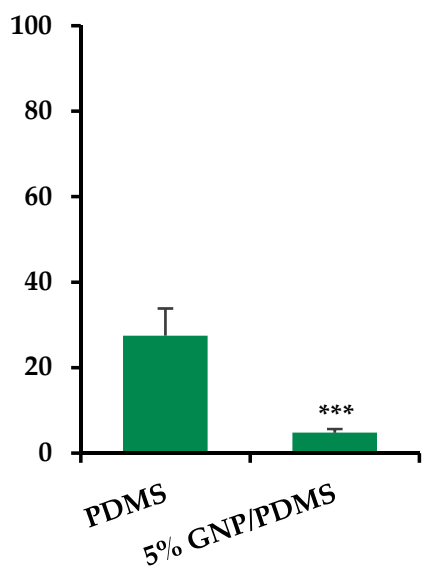

(a)

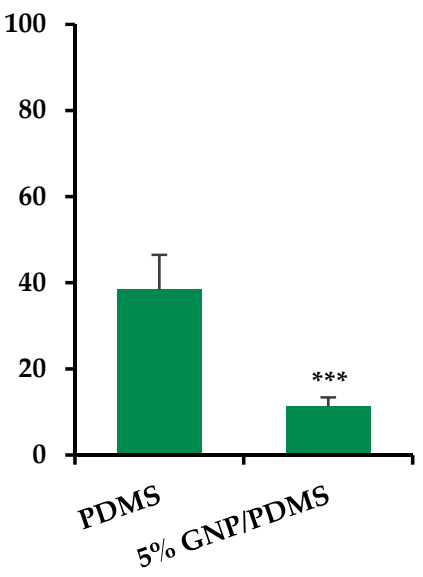

\section{P. aeruginosa + S. aureus}
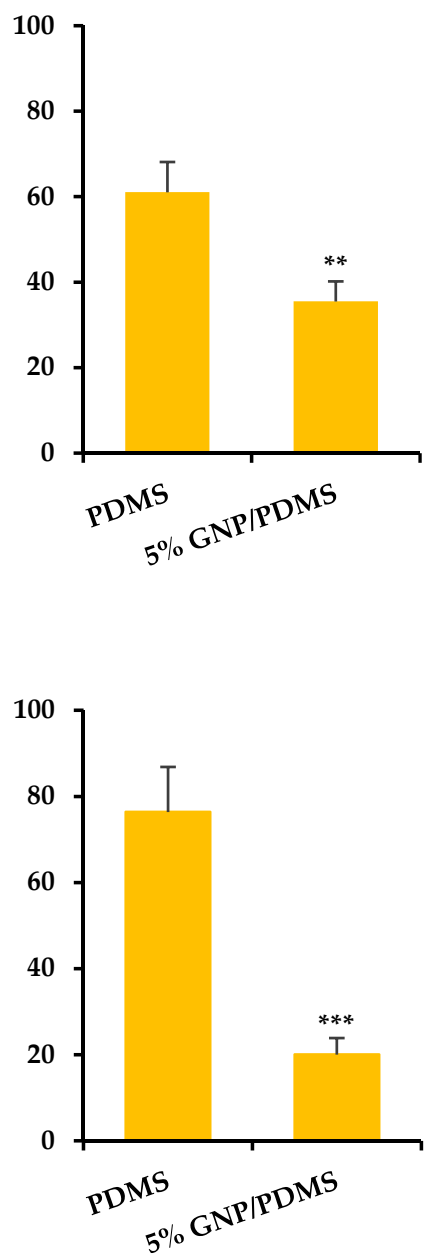

(b)

Figure 7. (a) Biovolumes and (b) thickness of P. aeruginosa and S. aureus single-species biofilms, and mixed biofilms (P. aeruginosa + S. aureus) on PDMS and $5 \mathrm{wt} \%$ GNP/PDMS surfaces. Both parameters were extracted from confocal files with the ImageJ software. The means \pm standard deviation are presented. Significant differences are represented for $p<0.01$ by ${ }^{* *}$ and $<0.001$ by ${ }^{* * *}$ when compared with PDMS.

This work demonstrates the antimicrobial activity of GNP/PDMS surfaces against single- and dual-species biofilms of S. aureus and P. aeruginosa. Although the studied pristine GNP-based materials combined good performance with the simplicity of preparation compared to functionalized composites, graphene functionalization with bioactive molecules and/or polymers may improve its antimicrobial performance. This will be explored in the future, as the percentages of biofilm reduction achieved here were lower than those reported in the literature for these particular bacteria in other coating systems for implantable medical devices [95]. For example, using nanocoatings based on magnetite, polyethyleneglycol, and a biologically active molecule (polymyxin B-PM), Caciandone and 
colleagues [95] were able to reduce S. aureus and P. aeruginosa culturable cells of up to four and five orders of magnitude, respectively.

Considering the ultimate goal of the produced GNP/PMDS coatings, cytotoxicity assays will be performed in the near future. However, it is known that, although graphenebased materials are not devoid of risks for the human body, they possess lower toxicity and higher biocompatibility than other carbon allotropes, including carbon nanotubes [96]. Furthermore, the vast majority of the studies in this field have shown that conjugating graphene with other biocompatible materials can help to create graphene materials with reduced bioaccumulation impact [97].

\section{Conclusions}

In this work, GNP/PDMS surfaces were produced and tested for the prevention of single- and dual-species biofilms of $S$. aureus and P. aeruginosa. It was shown that GNP/PDMS surfaces present high hydrophobicity and a good dispersion level, which are promising characteristics for the application of this carbon compound as an antibacterial agent.

Furthermore, biological assays showed that $5 \mathrm{wt} \%$ GNP loading was able to reduce the total and viable cell numbers of $S$. aureus and P. aeruginosa biofilms compared to PDMS. Although dual-species biofilms demonstrated higher resistance to the antimicrobial activity of $5 \mathrm{wt} \%$ GNP/PDMS surfaces, the performance of these coatings in inhibiting singleand dual-species biofilm cells was supported by confocal microscopy analysis, with a significant decrease in the two measured quantitative parameters-biofilm biovolume and thickness. Overall, the results obtained present enough potential to envisage a possible application of $5 \mathrm{wt} \%$ graphene/PDMS as an antimicrobial coating in biomedical devices. Future investigations are needed to evaluate the biocompatibility of these specific graphene derivatives, due to the lack of studies in the field.

Supplementary Materials: The following supporting information can be downloaded at: https:// www.mdpi.com/article/10.3390/nano12030355/s1, Figure S1: Spatial heterogeneity of dual-species biofilms of P. aeruginosa (labeled by the red fluorescent protein mCherry) and S. aureus (countermarked in green with Syto9) formed on $5 \mathrm{wt} \%$ GNP/PDMS: section views of the CLSM image presented in Figure 6f. Dotted white lines indicate vertical sections. Scale bar is $100 \mu \mathrm{m}$; Figure S2: Proportion of $S$. aureus (in blue) and P. aeruginosa (in orange) (a) culturable cells and (b) biovolume in dual-species biofilms formed on GNP/PDMS surfaces.

Author Contributions: Conceptualization, M.F.R.P., O.S.G.P.S. and F.J.M.; methodology, I.M.O., M.G., L.C.G. and O.S.G.P.S.; investigation, I.M.O., M.G., L.C.G. and O.S.G.P.S.; resources, M.F.R.P. and F.J.M.; data curation, I.M.O., M.G., L.C.G. and O.S.G.P.S.; writing—original draft preparation, I.M.O., M.G. and L.C.G.; supervision, M.F.R.P., O.S.G.P.S. and F.J.M.; funding acquisition, M.F.R.P. and F.J.M. All authors have read and agreed to the published version of the manuscript.

Funding: This work was financially supported by: Base-UIDB/50020/2020 and ProgrammaticUIDP/50020/2020 Funding of LSRE-LCM, funded by national funds through FCT/MCTES (PIDDAC). Base Funding-UIDB/00511/2020 of the Laboratory for Process Engineering, Environment, Biotechnology and Energy — LEPABE—funded by national funds through the FCT/MCTES (PIDDAC); and by Projects PTDC/CTM-COM/4844/2020 (NanoCAT) supported by national funds through the FCT/MCTES (PIDDAC) and NORTE-01-0145-FEDER-000054 (2SMART), supported by Norte Portugal Regional Operational Programme (NORTE 2020), under the PORTUGAL 2020 Partnership Agreement, through the European Regional Development Fund (ERDF). M.G. acknowledges the receipt of a PhD grant from FCT (2021.07149.BD). L.C.G. thanks FCT for the financial support of her work contract through the Scientific Employment Stimulus-Individual Call[CEECIND/01700/2017]. O.S.G.P.S. acknowledges FCT funding under the Scientific Employment Stimulus-Institutional Call CEECINST/00049/2018.

Institutional Review Board Statement: Not applicable.

Informed Consent Statement: Not applicable. 
Data Availability Statement: The data presented in this study are available on request from the corresponding authors. The data are not publicly available yet as some datasets are being used for additional publications.

Conflicts of Interest: The authors declare no conflict of interest.

\section{References}

1. Joung, Y.-H. Development of implantable medical devices: From an engineering perspective. Int. Neurourol. J. 2013, 17, 98-106. [CrossRef] [PubMed]

2. Ellouze, N.; Allouche, M.; Ahmed, H.B.; Rekhis, S.; Boudriga, N. Security of implantable medical devices: Limits, requirements, and proposals. Secur. Commun. Netw. 2014, 7, 2475-2491. [CrossRef]

3. Khatoon, Z.; McTiernan, C.D.; Suuronen, E.J.; Mah, T.-F.; Alarcon, E.I. Bacterial biofilm formation on implantable devices and approaches to its treatment and prevention. Heliyon 2018, 4, e01067. [CrossRef] [PubMed]

4. Weinstein, R.A.; Darouiche, R.O. Device-associated infections: A macroproblem that starts with microadherence. Clin. Infect. Dis. 2001, 33, 1567-1572. [CrossRef]

5. Li, X.; Sun, L.; Zhang, P.; Wang, Y. Novel Approaches to Combat Medical Device-Associated BioFilms. Coatings 2021, 11, 294. [CrossRef]

6. VanEpps, J.S.; Younger, J.G. Implantable device-related infection. Shock 2016, 46, 597-608. [CrossRef]

7. Lima, M.; Teixeira-Santos, R.; Gomes, L.C.; Faria, S.I.; Valcarcel, J.; Vázquez, J.A.; Cerqueira, M.A.; Pastrana, L.; Bourbon, A.I.; Mergulhão, F.J. Development of chitosan-based surfaces to prevent single- and dual-species biofilms of Staphylococcus aureus and Pseudomonas aeruginosa. Molecules 2021, 26, 4378. [CrossRef]

8. Oliva, A.; Miele, M.C.; Al Ismail, D.; Di Timoteo, F.; De Angelis, M.; Rosa, L.; Cutone, A.; Venditti, M.; Mascellino, M.T.; Valenti, P.; et al. Challenges in the microbiological diagnosis of implant-associated infections: A summary of the current knowledge. Front. Microbiol. 2021, 12, 750460. [CrossRef]

9. Jacobsen, S.M.; Stickler, D.J.; Mobley, H.L.T.; Shirtliff, M.E. Complicated catheter-associated urinary tract infections due to Escherichia coli and Proteus mirabilis. Clin. Microbiol. Rev. 2008, 21, 26-59. [CrossRef]

10. Tande, A.J.; Patel, R. Prosthetic joint infection. Clin. Microbiol. Rev. 2014, 27, 302-345. [CrossRef]

11. Haque, M.; Sartelli, M.; McKimm, J.; Abu Bakar, M. Health care-associated infections-An overview. Infect. Drug Resist. 2018, 11, 2321-2333. [CrossRef] [PubMed]

12. Folliero, V.; Franci, G.; Dell'Annunziata, F.; Giugliano, R.; Foglia, F.; Sperlongano, R.; De Filippis, A.; Finamore, E.; Galdiero, M. Evaluation of antibiotic resistance and biofilm production among clinical strain isolated from medical devices. Int. J. Microbiol. 2021, 2021, 9033278-9033288. [CrossRef] [PubMed]

13. Kandi, V.; Vadakedath, S. Implant-associated infections: A review of the safety of cardiac implants. Cureus 2020, 12 , e12267. [CrossRef]

14. Seebach, E.; Kubatzky, K.F. Chronic implant-related bone infections-can immune modulation be a therapeutic strategy? Front. Immunol. 2019, 10, 1724. [CrossRef]

15. Tiller, J.C. Chapter 18-Coatings for Prevention or Deactivation of Biological Contaminants. In Developments in Surface Contamination and Cleaning, 2nd ed.; Kohli, R., Mittal, K.L., Eds.; William Andrew Publishing: Oxford, UK, 2008; pp. 751-794.

16. Adlhart, C.; Verran, J.; Azevedo, N.F.; Olmez, H.; Keinänen-Toivola, M.M.; Gouveia, I.; Melo, L.F.; Crijns, F. Surface modifications for antimicrobial effects in the healthcare setting: A critical overview. J. Hosp. Infect. 2018, 99, 239-249. [CrossRef]

17. Tran, H.M.; Tran, H.; Booth, M.A.; Fox, K.E.; Nguyen, T.H.; Tran, N.; Tran, P.A. Nanomaterials for treating bacterial biofilms on implantable medical devices. Nanomaterials 2020, 10, 2253. [CrossRef]

18. Gomes, M.; Gomes, L.; Teixeira-Santos, R.; Mergulhão, F. PDMS in urinary tract devices: Applications, problems and potential solutions. In Polydimethylsiloxane: Structure and Applications, 1st ed.; Carlsen, P.N., Ed.; Nova Science Publishers: Hauppauge, NY, USA, 2020; pp. 95-144.

19. Tiwari, S.K.; Sahoo, S.; Wang, N.; Huczko, A. Graphene research and their outputs: Status and prospect. J. Sci.-Adv. Mater. Devices 2020, 5, 10-29. [CrossRef]

20. Teixeira-Santos, R.; Gomes, M.; Gomes, L.C.; Mergulhão, F.J. Antimicrobial and anti-adhesive properties of carbon nanotube-based surfaces for medical applications: A systematic review. Iscience 2020, 24, 102001. [CrossRef] [PubMed]

21. Mohan, V.B.; Lau, K.-t.; Hui, D.; Bhattacharyya, D. Graphene-based materials and their composites: A review on production, applications and product limitations. Compos. Part B Eng. 2018, 142, 200-220. [CrossRef]

22. Pandit, S.; Gaska, K.; Kádár, R.; Mijakovic, I. Graphene-based antimicrobial biomedical surfaces. ChemPhysChem 2021, 22, 250-263. [CrossRef]

23. Staneva, A.D.; Dimitrov, D.K.; Gospodinova, D.N.; Vladkova, T.G. Antibiofouling activity of graphene materials and graphenebased antimicrobial coatings. Microorganisms 2021, 9, 1839. [CrossRef]

24. Syama, S.; Mohanan, P.V. Comprehensive application of graphene: Emphasis on biomedical concerns. Nanomicro Lett. 2019, 11, 6 [CrossRef] [PubMed] 
25. Croitoru, A.-M.; Karaçelebi, Y.; Saatcioglu, E.; Altan, E.; Ulag, S.; Aydoğan, H.K.; Sahin, A.; Motelica, L.; Oprea, O.; Tihauan, B.-M.; et al. Electrically triggered drug delivery from novel electrospun poly(lactic acid)/graphene oxide/quercetin fibrous scaffolds for wound dressing applications. Pharmaceutics 2021, 13, 957. [CrossRef] [PubMed]

26. Yaragalla, S.; Bhavitha, K.B.; Athanassiou, A. A review on graphene based materials and their antimicrobial properties. Coatings 2021, 11, 1197. [CrossRef]

27. Szunerits, S.; Boukherroub, R. Antibacterial activity of graphene-based materials. J. Mater. Chem. B 2016, 4, 6892-6912. [CrossRef]

28. Mohammed, H.; Kumar, A.; Bekyarova, E.; Al-Hadeethi, Y.; Zhang, X.; Chen, M.; Ansari, M.S.; Cochis, A.; Rimondini, L. Antimicrobial mechanisms and effectiveness of graphene and graphene-functionalized biomaterials. a scope review. Front. Bioeng. Biotechnol. 2020, 8, 465-486. [CrossRef] [PubMed]

29. Kumar, P.; Huo, P.; Zhang, R.; Liu, B. Antibacterial properties of graphene-based nanomaterials. Nanomaterials 2019,9 , 737. [CrossRef]

30. Seifi, T.; Kamali, A.R. Anti-pathogenic activity of graphene nanomaterials: A review. Colloids Surf. B Biointerfaces 2021, 199, 111509. [CrossRef] [PubMed]

31. Zhao, M.; Shan, T.; Wu, Q.; Gu, L. The antibacterial effect of graphene oxide on Streptococcus mutans. J. Nanosci. Nanotechnol. 2020, 20, 2095-2103. [CrossRef]

32. Muthuchamy, M.; Govindan, R.; Shine, K.; Thangasamy, V.; Alharbi, N.S.; Thillaichidambaram, M.; Khaled, J.M.; Wen, J.L.; Alanzi, K.F. Anti-biofilm investigation of graphene/chitosan nanocomposites against biofilm producing P. aeruginosa and K. pneumoniae. Carbohydr. Polym. 2020, 230, 115646. [CrossRef]

33. Tian, T.; Shi, X.; Cheng, L.; Luo, Y.; Dong, Z.; Gong, H.; Xu, L.; Zhong, Z.; Peng, R.; Liu, Z. Graphene-based nanocomposite as an effective, multifunctional, and recyclable antibacterial agent. ACS Appl. Mater. Interfaces 2014, 6, 8542-8548. [CrossRef] [PubMed]

34. Dybowska-Sarapuk, Ł.; Kotela, A.; Krzemiński, J.; Wróblewska, M.; Marchel, H.; Romaniec, M.; Łegosz, P.; Jakubowska, M. Graphene nanolayers as a new method for bacterial biofilm prevention: Preliminary results. J. AOAC Int. 2017, 100, 900-904. [CrossRef] [PubMed]

35. Deng, C.-H.; Gong, J.-L.; Zeng, G.-M.; Jiang, Y.; Zhang, C.; Liu, H.-Y.; Huan, S.-Y. Graphene-CdS nanocomposite inactivation performance toward Escherichia coli in the presence of humic acid under visible light irradiation. Chem. Eng. J. 2016, 284, 41-53. [CrossRef]

36. Dubey, N.; Ellepola, K.; Decroix, F.E.D.; Morin, J.L.P.; Castro Neto, A.H.; Seneviratne, C.J.; Rosa, V. Graphene onto medical grade titanium: An atom-thick multimodal coating that promotes osteoblast maturation and inhibits biofilm formation from distinct species. Nanotoxicology 2018, 12, 274-289. [CrossRef] [PubMed]

37. Arshad, A.; Iqbal, J.; Mansoor, Q. Graphene $/ \mathrm{Fe}_{3} \mathrm{O}_{4}$ nanocomposite: Solar light driven fenton like reaction for decontamination of water and inhibition of bacterial growth. Appl. Surf. Sci. 2019, 474, 57-65. [CrossRef]

38. Gomes, R.N.; Borges, I.; Pereira, A.T.; Maia, A.F.; Pestana, M.; Magalhães, F.D.; Pinto, A.M.; Gonçalves, I.C. Antimicrobial graphene nanoplatelets coatings for silicone catheters. Carbon 2018, 139, 635-647. [CrossRef]

39. Hu, X.; Qian, W.; Li, X.; Fei, G.; Luo, G.; Wang, Z.; Xia, H. A novel method to prepare homogeneous biocompatible graphene-based PDMS composites with enhanced mechanical, thermal and antibacterial properties. Polym. Compos. 2018, 40, E1397-E1406. [CrossRef]

40. Tu, Q.; Zhang, Q.; Wang, Y.; Jiao, Y.; Xiao, J.; Peng, T.; Wang, J. Antibacterial properties of poly(dimethylsiloxane) surfaces modified with graphene oxide-catechol composite. Prog. Org. Coat. 2019, 129, 247-253. [CrossRef]

41. Qian, W.; Hu, X.; He, W.; Zhan, R.; Liu, M.; Zhou, D.; Huang, Y.; Hu, X.; Wang, Z.; Fei, G.; et al. Polydimethylsiloxane incorporated with reduced graphene oxide (rGO) sheets for wound dressing application: Preparation and characterization. Colloids Surf. $B$ 2018, 166, 61-71. [CrossRef] [PubMed]

42. Sardar, V.B.; Rajhans, N.; Pathak, A.; Prabhu, T. Developments in silicone material for biomedical applications-A review. In Proceedings of the 14th International Conference on Humanizing Work and Work Environment, Punjab, India, 8-11 December 2016; p. 14.

43. Victor, A.; Ribeiro, J.; Araújo, F.F. Study of PDMS characterization and its applications in biomedicine: A review. J. Mech. Eng. Biomech. 2019, 4, 1-9. [CrossRef]

44. Vagos, M.R.; Moreira, J.M.; Soares, O.S.; Pereira, M.F.; Mergulhão, F.J. Incorporation of carbon nanotubes in polydimethylsiloxane to control Escherichia coli adhesion. Polym. Compos. 2019, 40, E1697-E1704. [CrossRef]

45. Gomes, M.; Gomes, L.C.; Teixeira-Santos, R.; Pereira, M.F.R.; Soares, O.S.G.P.; Mergulhão, F.J. Optimizing CNT loading in antimicrobial composites for urinary tract application. Appl. Sci. 2021, 11, 4038. [CrossRef]

46. Rocha, R.P.; Silva, A.M.T.; Romero, S.M.M.; Pereira, M.F.R.; Figueiredo, J.L. The role of O- and S-containing surface groups on carbon nanotubes for the elimination of organic pollutants by catalytic wet air oxidation. Appl. Catal. B 2014, 147, 314-321. [CrossRef]

47. Janczuk, B.; Chibowski, E.; Bruque, J.M.; Kerkeb, M.L.; Caballero, F.G. On the consistency of surface free energy components as calculated from contact angles of different liquids: An application to the cholesterol surface. J. Colloid Interface Sci. 1993, 159, 421-428. [CrossRef]

48. van Oss, C.J.; Chaudhury, M.K.; Good, R.J. Monopolar surfaces. Adv. Colloid Interface Sci. 1987, 28, 35-64. [CrossRef]

49. van Oss, C.; Good, R.; Chaudhury, M. Additive and nonadditive surface tension components and the interpretation of contact angles. Langmuir 1988, 4, 884-891. [CrossRef] 
50. van Oss, C.J.; Ju, L.; Chaudhury, M.; Good, R. Estimation of the polar parameters of the surface tension of liquids by contact angle measurements on gels. J. Colloid Interface Sci. 1989, 128, 313-319. [CrossRef]

51. Kétyi, I. A model for testing drug susceptibility of Pseudomonas aeruginosa and Staphylococcus aureus grown in biofilms on medical devices. Acta Microbiol. Immunol. Hung. 1995, 42, 215-219. [PubMed]

52. El Mohtadi, M. Effect of Estrogen on Host-Pathogen Interactions in Ex Vivo and In Vitro Models of the Inflammatory Phase of Age-Related Impaired Healing. Ph.D. Thesis, Manchester Metropolitan University, Manchester, UK, 2019.

53. Gomes, L.; Silva, L.; Simões, M.; Melo, L.; Mergulhão, F. Escherichia coli adhesion, biofilm development and antibiotic susceptibility on biomedical materials. J. Biomed. Mater. Res. Part A 2015, 103, 1414-1423. [CrossRef] [PubMed]

54. Li, L.; Mendis, N.; Trigui, H.; Oliver, J.D.; Faucher, S.P. The importance of the viable but non-culturable state in human bacterial pathogens. Front. Microbiol. 2014, 5, 258. [CrossRef] [PubMed]

55. Gomes, L.C.; Deschamps, J.; Briandet, R.; Mergulhão, F.J. Impact of modified diamond-like carbon coatings on the spatial organization and disinfection of mixed-biofilms composed of Escherichia coli and Pantoea agglomerans industrial isolates. Int. J. Food Microbiol. 2018, 277, 74-82. [CrossRef] [PubMed]

56. Heydorn, A.; Nielsen, A.T.; Hentzer, M.; Sternberg, C.; Givskov, M.; Ersbøll, B.K.; Molin, S. Quantification of biofilm structures by the novel computer program COMSTAT. Microbiology 2000, 146, 2395-2407. [CrossRef] [PubMed]

57. Anovitz, L.M.; Cole, D.R. Characterization and analysis of porosity and pore structures. Rev. Mineral. Geochem. 2015, 80, 61-164. [CrossRef]

58. Sing, K.S.W. Reporting physisorption data for gas/solid systems with special reference to the determination of surface area and porosity (Provisional). Pure Appl. Chem. 1982, 54, 2201-2218. [CrossRef]

59. Solís, R.R.; Mena, I.F.; Nadagouda, M.N.; Dionysiou, D.D. Adsorptive interaction of peroxymonosulfate with graphene and catalytic assessment via non-radical pathway for the removal of aqueous pharmaceuticals. J. Hazard. Mater. 2020, 384, 121340. [CrossRef]

60. Daş, E.; Kaplan, B.Y.; Gürsel, S.A.; Yurtcan, A.B. Graphene nanoplatelets-carbon black hybrids as an efficient catalyst support for Pt nanoparticles for polymer electrolyte membrane fuel cells. Renew. Energy 2019, 139, 1099-1110. [CrossRef]

61. Lee, G.-J.; Rhee, C.K. Enhanced thermal conductivity of nanofluids containing graphene nanoplatelets prepared by ultrasound irradiation. J. Mater. Sci. 2014, 49, 1506-1511. [CrossRef]

62. Wang, Z.; Zhang, X.; Liu, X.; Lv, M.; Yang, K.; Meng, J. Co-gelation synthesis of porous graphitic carbons with high surface area and their applications. Carbon 2011, 49, 161-169. [CrossRef]

63. Zhang, S.; Wang, H.; Liu, J.; Bao, C. Measuring the specific surface area of monolayer graphene oxide in water. Mater. Lett. 2020, 261, 127098. [CrossRef]

64. Srinivas, G.; Zhu, Y.; Piner, R.; Skipper, N.; Ellerby, M.; Ruoff, R. Synthesis of graphene-like nanosheets and their hydrogen adsorption capacity. Carbon 2010, 48, 630-635. [CrossRef]

65. Zawadzka, K.; Kądzioła, K.; Felczak, A.; Wrońska, N.; Piwoński, I.; Kisielewska, A.; Lisowska, K. Surface area or diameter-which factor really determines the antibacterial activity of silver nanoparticles grown on $\mathrm{TiO}_{2}$ coatings? New J. Chem. 2014, 38, 3275-3281. [CrossRef]

66. Morris, R.E. Microporous Materials in Antibacterial Applications. In Antimicrobial Coatings and Modifications on Medical Devices; Zhang, Z., Wagner, V.E., Eds.; Springer: Cham, Switzerland, 2017; pp. 171-188.

67. Renner, L.D.; Weibel, D.B. Physicochemical regulation of biofilm formation. MRS Bull. 2011, 36, 347-355. [CrossRef] [PubMed]

68. Wang, J.-N.; Zhang, Y.-L.; Liu, Y.; Zheng, W.; Lee, L.P.; Sun, H.-B. Recent developments in superhydrophobic graphene and graphene-related materials: From preparation to potential applications. Nanoscale 2015, 7, 7101-7114. [CrossRef]

69. McCallion, C.; Burthem, J.; Rees-Unwin, K.; Golovanov, A.; Pluen, A. Graphene in therapeutics delivery: Problems, solutions and future opportunities. Eur. J. Pharm. Biopharm. 2016, 104, 235-250. [CrossRef]

70. Wang, P.; Yao, T.; Sun, B.; Fan, X.; Dong, S.; Bai, Y.; Shi, Y. A cost-effective method for preparing mechanically stable anti-corrosive superhydrophobic coating based on electrochemically exfoliated graphene. Colloid Surf. A Physicochem. Eng. Asp. 2017, 513, 396-401. [CrossRef]

71. Wu, S.; Zuber, F.; Maniura-Weber, K.; Brugger, J.; Ren, Q. Nanostructured surface topographies have an effect on bactericidal activity. J. Nanobiotechnol. 2018, 16, 20. [CrossRef]

72. Gong, J.; Zhou, Z.; Sumathy, K.; Yang, H.; Qiao, Q. Activated graphene nanoplatelets as a counter electrode for dye-sensitized solar cells. J. Appl. Phys. 2016, 119, 135501. [CrossRef]

73. Borges, I.; Henriques, P.C.; Gomes, R.N.; Pinto, A.M.; Pestana, M.; Magalhães, F.D.; Gonçalves, I.C. Exposure of smaller and oxidized graphene on polyurethane surface improves its antimicrobial performance. Nanomaterials 2020, 10, 349. [CrossRef]

74. Radhi, A.; Mohamad, D.; Rahman, F.S.A.; Abdullah, A.M.; Hasan, H. Mechanism and factors influence of graphene-based nanomaterials antimicrobial activities and application in dentistry. J. Mater. Res. Technol. 2021, 11, 1290-1307. [CrossRef]

75. Liu, S.; Zeng, T.H.; Hofmann, M.; Burcombe, E.; Wei, J.; Jiang, R.; Kong, J.; Chen, Y. Antibacterial activity of graphite, graphite oxide, graphene oxide, and reduced graphene oxide: Membrane and oxidative stress. ACS Nano 2011, 5, 6971-6980. [CrossRef] [PubMed]

76. Sun, W.; Wu, F.G. Two-dimensional materials for antimicrobial applications: Graphene materials and beyond. Chem. Asian J 2018 13, 3378-3410. [CrossRef] [PubMed] 
77. Zhang, X.; Wang, L.; Levänen, E. Superhydrophobic surfaces for the reduction of bacterial adhesion. Rsc Adv. 2013, 3, 12003-12020. [CrossRef]

78. Yuan, Y.; Hays, M.P.; Hardwidge, P.R.; Kim, J. Surface characteristics influencing bacterial adhesion to polymeric substrates. RSC Adv. 2017, 7, 14254-14261. [CrossRef]

79. Liu, S.; Cao, S.; Guo, J.; Luo, L.; Zhou, Y.; Lin, C.; Shi, J.; Fan, C.; Lv, M.; Wang, L. Graphene oxide-silver nanocomposites modulate biofilm formation and extracellular polymeric substance (EPS) production. Nanoscale 2018, 10, 19603-19611. [CrossRef]

80. Wu, X.; Tan, S.; Xing, Y.; Pu, Q.; Wu, M.; Zhao, J.X. Graphene oxide as an efficient antimicrobial nanomaterial for eradicating multi-drug resistant bacteria in vitro and in vivo. Colloids Surf. B Biointerfaces 2017, 157, 1-9. [CrossRef]

81. Di Giulio, M.; Zappacosta, R.; Di Lodovico, S.; Di Campli, E.; Siani, G.; Fontana, A.; Cellini, L. Antimicrobial and antibiofilm efficacy of graphene oxide against chronic wound microorganisms. Antimicrob. Agents Chemother. 2018, 62, e00547-18. [CrossRef]

82. Khan, A.; Ameen, F.; Khan, F.; Al-Arfaj, A.; Ahmed, B. Fabrication and antibacterial activity of nanoenhanced conjugate of silver (I) oxide with graphene oxide. Mater. Today Commun. 2020, 25, 101667-101675. [CrossRef]

83. Dat, N.M.; Long, P.N.B.; Nhi, D.C.U.; Minh, N.N.; Duy, L.M.; Quan, L.N.; Nam, H.M.; Phong, M.T.; Hieu, N.H. Synthesis of silver/reduced graphene oxide for antibacterial activity and catalytic reduction of organic dyes. Synth. Met. 2020, $260,116260$. [CrossRef]

84. Wang, H.; Zhang, Y.; Xu, X.; Yang, F.; Li, K.; Wei, D.; Liu, Z. Efficient loading of silver nanoparticles on graphene oxide and its antibacterial properties. Nano Express 2020, 1, 010041. [CrossRef]

85. Rago, I.; Bregnocchi, A.; Zanni, E.; D’Aloia, A.G.; De Angelis, F.; Bossu, M.; De Bellis, G.; Polimeni, A.; Uccelletti, D.; Sarto, M.S. Antimicrobial activity of graphene nanoplatelets against Streptococcus mutans. In Proceedings of the IEEE International Conference on Nanotechnology, Rome, Italy, 27-30 July 2015; pp. 9-12.

86. Bregnocchi, A.; Zanni, E.; Uccelletti, D.; Marra, F.; Cavallini, D.; De Angelis, F.; De Bellis, G.; Bossu, M.; Ierardo, G.; Polimeni, A.; et al. Graphene-based dental adhesive with anti-biofilm activity. J. Nanobiotechnology 2017, 15, 89. [CrossRef]

87. Scaffaro, R.; Botta, L.; Maio, A.; Gallo, G. PLA graphene nanoplatelets nanocomposites: Physical properties and release kinetics of an antimicrobial agent. Compos. Part B Eng. 2017, 109, 138-146. [CrossRef]

88. Bregnocchi, A.; Zanni, E.; Rago, I.; Paliotta, L.; Bellis, G.D.; Uccelletti, D.; Sarto, M.S. Antimicrobial activity of graphene nanoplatelets against Staphylococcus aureus. In Proceedings of the GraphIta 2015, Bologna, Italy, 14-18 September 2015.

89. Zanni, E.; Bruni, E.; Chandraiahgari, C.; De Bellis, G.; Santangelo, M.; Leone, M.; Bregnocchi, A.; Mancini, P.; Sarto, M.; Uccelletti, D. Evaluation of the antibacterial power and biocompatibility of zinc oxide nanorods decorated graphene nanoplatelets: New perspectives for antibiodeteriorative approaches. J. Nanobiotechnology 2017, 15, 57. [CrossRef]

90. Pulingam, T.; Thong, K.L.; Ali, M.E.; Appaturi, J.N.; Dinshaw, I.J.; Ong, Z.Y.; Leo, B.F. Graphene oxide exhibits differential mechanistic action towards Gram-positive and Gram-negative bacteria. Colloids Surf. B Biointerfaces 2019, 181, 6-15. [CrossRef] [PubMed]

91. Akhavan, O.; Ghaderi, E. Toxicity of graphene and graphene oxide nanowalls against bacteria. ACS Nano 2010, 4, 5731-5736. [CrossRef]

92. McIntyre, J.; Verma, N.; Smith, R.; Rezvani, E.; Duesberg, G.; Coleman, J.; Volkov, Y. Biocompatibility of pristine graphene monolayers, nanosheets and thin films. arXiv 2014, arXiv:1406.2497.

93. Dehbashi, S.; Alikhani, M.Y.; Tahmasebi, H.; Arabestani, M.R. The inhibitory effects of Staphylococcus aureus on the antibiotic susceptibility and virulence factors of Pseudomonas aeruginosa: A549 cell line model. AMB Express 2021, 11, 50. [CrossRef] [PubMed]

94. Kim, S.; Yoon, Y.; Choi, K.H. Pseudomonas aeruginosa DesB promotes Staphylococcus aureus growth inhibition in coculture by controlling the synthesis of HAQs. PLoS ONE 2015, 10, e0134624. [CrossRef]

95. Caciandone, M.; Niculescu, A.-G.; Roșu, A.R.; Grumezescu, V.; Negut, I.; Holban, A.M.; Oprea, O.; Vasile, B.S.; Bîrcă, A.C.; Grumezescu, A.M.; et al. PEG-functionalized magnetite nanoparticles for modulation of microbial biofilms on voice prosthesis. Antibiotics 2022, 11, 39. [CrossRef]

96. Mendes, R.G.; Bachmatiuk, A.; Büchner, B.; Cuniberti, G.; Rümmeli, M.H. Carbon nanostructures as multi-functional drug delivery platforms. J. Mater. Chem. B 2013, 1, 401-428. [CrossRef] [PubMed]

97. Zhang, Q.; Wu, Z.; Li, N.; Pu, Y.; Wang, B.; Zhang, T.; Tao, J. Advanced review of graphene-based nanomaterials in drug delivery systems: Synthesis, modification, toxicity and application. Mater. Sci. Eng. C 2017, 77, 1363-1375. [CrossRef] 